\title{
大血管転換術後の無症候性冠動脈閉塞に伴う 心筋虚血と突然死
}

Nemours Cardiac Center, Nemours/Alfred I. duPont Hospital for Children 津 田武 武

\section{はじめに}

近年の手術技術や術中・術後管理の目まぐるし い進歩により, 先天性心疾患患者の術後の早期予 後は著しく向上した，完全大血管転位症（transposition of the great arteries: d-TGA) は新生児 期に発症する重篤なチアノーゼ心疾患であるが, 大血管転換術 (arterial switch operation: ASO, Jatene 術）の普及により, 特別な例外の除いて, ほとんどの患者の生存が期待できるようになつ た. 多くの患者が長期生存をする一方, 思春期や 成人期における遠隔期の合併症がより注目され るに至った ${ }^{1)}$. ASO 術後の長期合併症としては, (1) 右室流出路狭窄と主肺動脈狭窄，(2)大動脈拡 張と大動脈弁閉鎖不全, (3) 冠動脈病変と心筋虚 血, (4) 不整脈と (5) 突然死などが長期合併症とし て報告され，生涯にわたるフォローアップの重要 さが強調されている ${ }^{1)}$. 特に冠動脈病変と心筋虚 血に関しては, 診断が困難であるばかりでなく, 時に予期しない致死的な転機を伴うことが知られ ている。しかしながら，その病因・病態生理に関 してはまだ不明な点が多い。本稿では, ASO 術 後の遠隔期における冠動脈狭窄の臨床的意義と今 後の対策について述べていきたい.

\section{ASO 術後の冠動脈病変と心筋虚血}

ASO 術後早期の冠動脈合併症は, 術前の冠動 脈の特殊な形態異常や冠動脈移転の手術手技の難 易度に関連していると考えられているが, 遠隔期 における冠動脈病変発生のメカニズムは, まだ明 確には解明されていない. 冠動脈狭窄の合併頻度 は, 一般的に肺動脈・右室流出路や大動脈の異常 に比べ比較的少ないが, 筆者 ${ }^{2}$ やその他のグルー プ3 7) の報告ではその頻度は決して低くない（3〜 8\%). 患者は無症状であることが多く, 狭心痛な ごの成人によくみられる症状を訴えることはほと んどない. 最初の症状が予期せぬ突然死である場 合も少なくないので, 発生時の社会的インパクト は大きい ${ }^{2)}$. 病理組織所見では血管内膜の肥厚 intimal thickening が主所見であるが，その成因は まだ明確には解明されていない.また遠隔期の冠 動脈病変は, 術前の冠動脈の形態とはあまり相関 を持たないが4), その狭窄度は時間とともに進行 することが知られている ${ }^{8)}$. ASO 後の冠動脈狭窄 の早期診断に関しては，まだ確立されたガイドラ インは存在しない.

\section{無症状冠動脈病変の診断と問題点}

小児期の無症候性の冠動脈狭窄病変は, 通常の

\footnotetext{
[Key words $]$ 遠隔期合併症, 完全大血管転位症（transposition of the great arteries）,
} 大血管転換術 (arterial switch operation), 冠動脈狭窄, 心筋虚血 
外来検査 (心電図・心エコー) で検出されること はほとんどない。成人においては, 運動負荷試 験 exercise stress test (EST) ・心筋シンチグラ フィー myocardial perfusion imaging (MPI) が 無症候性冠動脈病変の検出に有効であると考えら れているが, ASO 後の冠動脈病変の診断にはあ まり有効であるとは言えない. Legendre らは, 心電図・心エコー・EST・MPI による総合診断で は, ASO 後の冠動脈病変の検出に関して sensitivity $73 \%$, specificity $74 \%$ と報告している7). Acar らは, MPI 単独による冠動脈異常の検出率 を sensitivity $69 \%$, specificity $73 \%$ と報告して いる ${ }^{9)}$. 言い換えれば，冠動脈画像診断を用いな い限り， 4 例に 1 例はこの病変を見逃すというこ とになる. 冠動脈病変の診断の gold standard は 血管造影であるが, 最近では CT coronary angiography（CTCA）が従来の血管造影に取つて代 わるようになってきた ${ }^{10)}$. 見逃せば致死的な転機 をとる可能性も高い ASO 後の冠動脈病変は, ぞ のようにして有効に診断すればよいのだろうか? あるいは突然死予防のためには, ASO 後の患者 は全員ある時期に冠動脈の画像診断を必要とする のであろうか?

\section{ASO 後の冠動脈病変の実態}

筆者らは, 最近 ASO 後の長期冠動脈病変の発 生に関して, 所属する小児病院 Alfred I. duPont Hospital for Children での臨床経験を報告した ${ }^{2)}$. 術後 1 年以上（1～25.6年：中央值8.25年）外来 フォローしている97名（男63名，女34名）の患者 のうち, 冠動脈検査が施行された40名を対象とし た (39名は心カテ時の血管造影, 1 名は剖検例). 術後 1 年以内の死亡例, 心不全（重度の左室機能 不全）合併例, 心筋梗塞の既往例, 心内膜炎の既 往例, 重度の術後神経障害を合併した例などは除 外した. 心力テ・血管造影の適応としては, 1)心 エコー上の血行動態異常や心電図異常, 2) 競争ス ポーツ参加前の心機能の評価の一環, 3) 臨床症状 (胸痛, 動悸, 運動不耐性など), 4) 非定型的な術
前の冠動脈形態，5) EST や MPI による心筋虚血 の疑い, などが挙げられた。

合計 7 名の患者に著明な冠動脈異常が認めら れたが (4名: 完全閉塞, 2 名: 重度狭窄, 1 名: 中等度狭窄), 通常の外来診療で何らかの症状を 訴えたものは皆無であった。 4 名の完全閉塞例で は, 全例に側副血行路 collateral vessels の形成 が認められた. 2 名の重度狭窄患者には側副血行 路がみられず，このうち 1 名は自宅で突然腹痛を 訴えたのちに全身けいれんを起こした死亡例 (3.8 歳）と, もう 1 名は運動中に突然心室細動を発症 して倒れたが, 幸いにも現場で除細動と適切な心 肺蘇生を受け救命された例であった（9.6歳）。死 亡例の剖検所見では, 左冠動脈主幹部において高 度の内膜肥厚が認められたが, 肉眼的に心筋梗塞 の所見は観察されなかった。 2 番目の例では, 血 管造影上高度の左冠動脈起始部の狭窄が認めら れ, 左冠動脈の形成術時には主幹部にフラップ様 の内膜肥厚が認められた。この患者は, 左冠動脈 主幹部形成術を受けて現在も元気にしている。心 筋梗塞の合併はなかった. いずれの例も, 外来で の心電図・心エコーでは心筋虚血を示唆する所見 は認められなかった. 特に後者は, 心室細動発症 10 カ前の EST および MPI では運動負荷によ る心筋虚血の所見はまったく認められず, 最大酸 素消費量測定でも予測值以上の良好な運動能力を 示していた. 冠動脈異常をきたした 7 名のうち, EST MPI にて異常所見を示したものは 2 名の みであった. 左冠動脈前下行枝完全閉塞と診断さ れた9.5歳の患者（回旋枝は右冠動脈から起始, 左前下行枝も側副血行路にて右冠動脈とつながつ ていた）は，臨床的にはまったく無症状であっ たが，ESTにて最大運動時に胸部側壁誘導にて (V4-V6) $7 \mathrm{~mm}$ のST-T 低下を認め, MPI では 左室側壁に還流欠損を認めた。ただし，最大運動 時でも患者はまったく無症状であった。この患者 は, 後日左冠動脈のバイパス手術を受け, 現在も 健康でスポーツを楽しんでいる. また他の 3 名に おいては, 複数回の血管造影による冠動脈形態の 観察から，10年以上の期間において冠動脈の血管 
狭窄度の進行が証明された。これら 7 名以外に も, 他の 4 名の患者に血管造影上の軽度の冠動脈 の狭小化を認めた．これらの軽微な変化の臨床的 意義は不明である.

$\mathrm{ASO}$ 後の冠動脈病変の発生は, われわれの経 験では $7.2 \%$ と推定されたが, すべての患者が冠 動脈画像診断を受けたわけではないので, 実際 の頻度はこの数字よりも高い可能性がある. ま た, ASO 後の突然死の可能性は $2.1 \%(2 / 97)$ で あった.この数字は決して小さなものではなく, 突然死の原因と考えられる先天性冠動脈異常 (aberrant aortic origin of left coronary artery: AAOLCA $)^{11)}$ の頻度と比べてみても, 桁違いに高 い頻度であることが分かる，それでは，この致死 性の高い病変をどのように識別・診断してゆくの が妥当なのだろうか?

\section{ASO 後の冠動脈スクリーニングと 心筋虚血・突然死の risk stratification}

$\mathrm{ASO}$ 後の遠隔期における冠動脈病変の特徵を 列挙してみると, 1) 血管狭窄・閉塞のメカニズム がまだ解明されていない, 2) 冠動脈病変の程度と 術前の冠動脈のパターンや術後早期の合併症の有 無とはほとんど関連しない，3）心筋虚血を示唆す る臨床症状（胸痛, 眩量, 動悸など）に乏しい, 4) 冠動脈画像診断をしない限り診断が困難であ る(心電図, 心エコー, EST, MPI などの外来 検査で冠動脈異常の有無を予測することは極めて 困難)，5）まったく無症状な患者が予期せぬ突然 死で発症することがある, などがある. 同様の特 徵は, 前述した AAOLCA にも認められる. 小児 循環器医にとっての最大の難題は, このまれであ るが時に致死的にもなりうる病態に日常診療で遭 遇する機会が極めて少ない，という事実である.

したがって, 成人における心筋虚血や心筋梗塞の 病態生理・臨床症状をしばしばそのまま小児にも 当てはめて考えがちになるが, これは発症のメカ ニズムを考えれば明らかに不適切である，心筋虚 血を引き起こす病因が異なるばかりでなく，心筋
虚血自体が引き起こす生物学的病理 pathobiology も成人と小児とでは異なるからである.

小児科領域でも心筋虚血をきたす疾患をいくつ か挙げることができる. 先天性のものとしては, 左冠動脈肺動脈起始症 (anomalous left coronary artery from pulmonary artery: ALCAPA), 前述 の AAOLCA, 肺動脈閉鎖 - 正常心室中隔（pulmonary atresia with intact ventricular septum: PA/IVS) で右室依存冠動脈 RV-dependent coronary artery を合併したもの, 後天性のものとし ては, 川崎病で巨大冠動脈瘤を合併したもの, ASO 後の冠動脈狭窄・閉塞, 心移植後の冠動脈 病変 cardiac allograft vasculopathy or CAVなど が含まれる ${ }^{12)}$. 成人に頻繁にみられる動脈硬化 atherosclerosis に伴う虚血性心疾患は, 小児期に は少ない。.また同じ虚血という刺激に対しても, 心筋組織は (1) 細胞死へのプロセス (心筋梗塞) と(2) 電気的不安定性 electrical instability（心室 細動・突然死）という2つの経路を引き起こす. いずれも細胞内のカルシウム動態の異常やミトコ ンドリアの機能不全を介して発現されるが，その メカニズムは複雑である ${ }^{12)}$. AAOLCA や ASO 後の冠動脈狭窄は, 心筋の正常な調律・刺激伝導 を乱すことにより心室細動・突然死として発症す ることが多く, 一方 ALCAPA や PA/IVS や川崎 病の冠動脈瘤では虚血による直接の組織障害とし ての心筋梗塞として発症することが多い. CAV はどちらの経路も取りうる。したがって, ASO 後の冠動脈病変のように突然死をきたす心筇虚血 に対しては, 通常の狭心痛で発症する心筋虚血と 同じ対応をしてはならない.この 2 つの経路の分 子生物学的なメカニズムを理解するためには, よ り進んだ基礎研究の発展が期待される.

ASO 後の遠隔期における冠動脈病変識別のた めの公に認められたガイドラインは, まだ存在し ない.われわれの施設では, 2016年より表 1 に掲 げてあるようなガイドラインに従っている.すべ ての ASO 後の患者は冠動脈画像診断の適応を もっているが, 施行時期としては (1) 臨床症状 (胸痛, 動悸, 運動不耐症など) や異常所見（心 
表 1 Proposed Management Strategy for Preclinical Coronary Lesions in Post-ASO patients at Nemours Cardiac Center (2016)

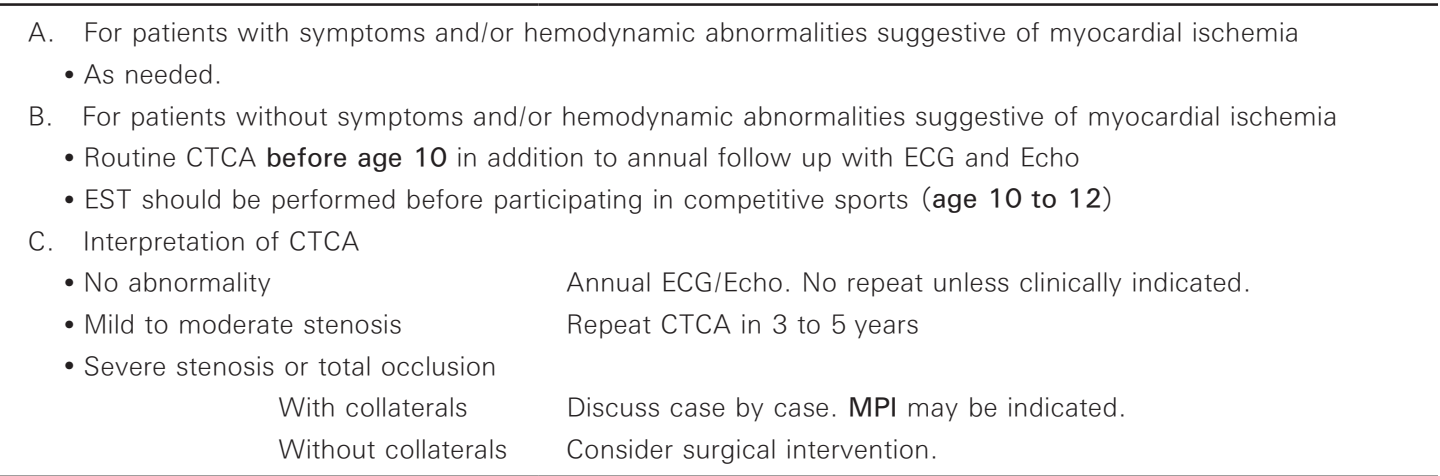

CTCA: CT coronary angiography, MPI: myocardial perfusion imaging.

電図・心エコーの異常) 存在時は随時に, (2)まつ たく無症状で臨床検査上の異常所見がない場合で も10歳くらいまでに一度，と勧めている．現在は 従来の血管造影の代わりに, CTCA を第一選択と するようになつた（特に冠動脈の形態のみを吟味 する場合)。CTCA は, 画像解像度 resolution, 検査所要時間（実質 1 分以内）, 検査の非侵襲来 性という観点からも非常に有効な検査だと言え る. 放射線被曝量も従来に比べてかなり軽減でき るようになつた。 今後は血管病変診断の信頼性や 放射線被曝の問題から cost-benefit-performance に関してさらなる議論が必要になるかも知れな い. ちなみにフランスのグループでは，すべての ASO 後の患者に対して術後5，10，15年後の定期 的な冠動脈画像診断を推奨している77).

\section{結 語}

ASO 後の冠動脈病変は, 術後遠隔期において 予期せぬ突然死の原因となりうるので，その早期 診断は極めて重要である。この冠動脈病変は, 成 人にみられる狭心痛などの臨床症状はほとんど伴 わないので，遠隔期においては症状の有無にかか わらず積極的な早期診断が必要である. ASO 後 の冠動脈病変の本質を理解するためには, 多施 設間での共同研究が必須と考えられる。 また虚血 性心疾患は, 成人期にしばしばみられる病態で,
$\mathrm{ASO}$ 後の患者は特にそのリスクファクターとな る喫煙 - 糖尿病 - 肥満 - 高血圧 - 高脂血症の予防 に細心の留意を必要とする.

著者の COI (conflicts of interest) 開示 : 本論文発表 に関連して特に申告なし

\section{文献}

1) Villafane J, Lantin-Hermoso $\mathrm{MR}$, Bhatt $\mathrm{AB}$, et al: American College of Cardiology's Adult C and Pediatric Cardiology C. D-transposition of the great arteries: the current era of the arterial switch operation. J Am Coll Cardiol 2014; 64: 498-511

2) Tsuda T, Bhat AM, Robinson BW, et al: Coronary Artery Problems Late After Arterial Switch Operation for Transposition of the Great Arteries. Circ J 2015; 79: 2372-2379

3) Losay J, Touchot A, Serraf A, et al: Late outcome after arterial switch operation for transposition of the great arteries. Circulation 2001; 104: I121-126

4) Hutter PA, Kreb DL, Mantel SF, et al: Twenty-five years' experience with the arterial switch operation. J Thorac Cardiovasc Surg 2002; 124: 790-797

5) Ou P, Mousseaux E, Azarine A, et al: Detection of coronary complications after the arterial switch operation for transposition of the great arteries: first experience with multislice computed tomography in children. J Thorac Cardiovasc Surg 2006; 131: 639643

6) El-Segaier M, Lundin A, Hochbergs P, et al: Late coronary complications after arterial switch operation 
and their treatment. Catheter Cardiovasc Interv 2010; 76: 1027-1032

7) Legendre A, Losay J, Touchot-Kone A, et al: Coronary events after arterial switch operation for transposition of the great arteries. Circulation 2003; 108 Suppl 1: II186-190

8) Raisky O, Bergoend E, Agnoletti G, et al: Late coronary artery lesions after neonatal arterial switch operation: results of surgical coronary revascularization. Eur J Cardiothorac Surg 2007; 31: 894-898

9) Acar P, Maunoury C, Bonnet D, et al: Comparison of myocardial perfusion single-photon emission computed tomography with coronary artery angiography after arterial switch operation. Am J Cardiol 2001; 87: $1425-1427$
10) Ou P, Celermajer DS, Marini D, et al: Safety and accuracy of 64-slice computed tomography coronary angiography in children after the arterial switch operation for transposition of the great arteries. JACC Cardiovasc Imaging 2008; 1: 331-339

11) Basso C, Maron BJ, Corrado D, et al: Clinical profile of congenital coronary artery anomalies with origin from the wrong aortic sinus leading to sudden death in young competitive athletes. J Am Coll Cardiol 2000; 35: 1493-1501

12) Tsuda T: Preclinical coronary artery anomalies and silent myocardial ischemia in children: How can we identify the potential life-threatening conditions? J Ped Cardiol Card Surg 2017; 1: 1-12 